\title{
Physical activity learning by medical students: the current picture in Brazil
}

\author{
Aprendizagem sobre atividade física por estudantes de Medicina: a situação hoje no Brasil
}

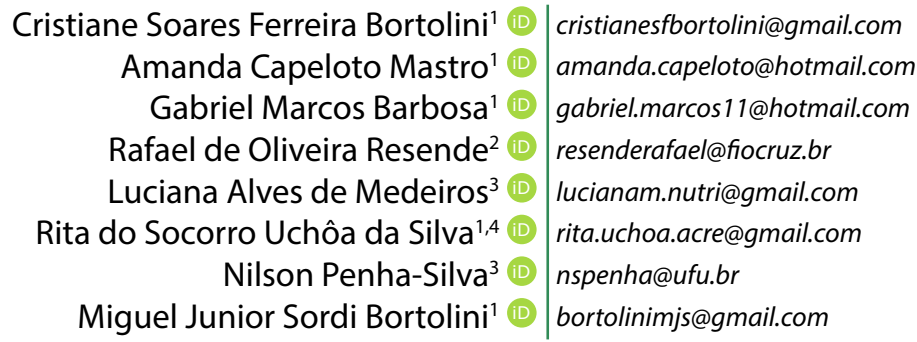

\begin{abstract}
Introduction: Physical activity is essential for preventing and treating many diseases. Although physicians are the most influential health professionals in advising their patients on the benefits of physical activity, most medical degree programs in Brazil do not seem to include physical activity topics in their curricula.
\end{abstract}

Objective: This study aimed to investigate physical activity topics on active medical curricula in Brazil.

Method: The research was conducted separately in April 2015 and February 2019 using a governmental resource, the e-MEC system, and search in internet databases. Data were split into categories according to the type of enrollment (mandatory or optional) of the courses that have subjects or thematic modules with topics on physical activity, type of activities (theoretical, practical, or theoretical-practical), and emphasis on the content (health, performance, or health and performance).

Results: Of the 223 medical curricula compiled in 2015 and 286 in 2019, respectively, only 24 (10.8\%) and 19 (6.7\%) had at least one subject or thematic module concerning physical activity with emphasis on health.

Conclusion: In Brazil, the number of undergraduate medical curricula covering physical activity topics is still small and suffered a reduction between 2015 and 2019, which should warn medical education institutions about the need to include physical activity longitudinally distributed contents, with theoretical and - if possible - practical approaches, and emphasis on health promotion and treatment of diseases, in mandatory curricular units.

Keywords: Medical Education; Curriculum; Physical Exercise; Quality of Life; Prevention; Chronic Diseases; Sedentary Lifestyle.

\section{RESUMO}

Introdução: A atividade física é essencial para prevenir e tratar muitas doenças. Embora os médicos sejam os profissionais de saúde que mais influenciam a orientação de seus pacientes sobre os benefícios da atividade física, a maioria dos programas de graduação em Medicina no Brasil parece não incluir tópicos sobre atividade física em seus currículos.

Objetivo: Este estudo teve como objetivo investigar a presença de tópicos sobre atividade física nos currículos médicos ativos no Brasil.

Método: A pesquisa foi realizada separadamente em abril de 2015 e fevereiro de 2019, utilizando um recurso governamental, o sistema e-MEC, e pesquisa em bancos de dados da internet. Os dados foram divididos em categorias, de acordo com a condição de matrícula (obrigatória ou opcional) dos cursos com disciplinas ou módulos temáticos contendo tópicos sobre atividade física, tipo de atividades (teóricas, práticas ou teórico-práticas) e ênfase no conteúdo (saúde, desempenho ou saúde e desempenho).

Resultado: Dos 223 currículos médicos compilados em 2015 e 286 em 2019, respectivamente, apenas 24 (10,8\%) e 19 (6,7\%) apresentaram pelo menos uma disciplina ou módulo temático contendo tópico sobre atividade física com ênfase em saúde.

Conclusão: No Brasil, o número de currículos de graduação em Medicina contemplando tópicos de atividade física ainda é pequeno e sofreu uma redução entre 2015 e 2019, o que deve servir de alerta para as instituições de ensino médico quanto à necessidade de inclusão de conteúdos longitudinalmente distribuídos sobre atividade física, com abordagens teórica e, se possível, prática, e com ênfase na promoção da saúde e no tratamento de doenças, em unidades curriculares obrigatórias.

Palavras-chave: Educação Médica; Currículo; Exercício Físico; Qualidade de Vida; Prevenção; Doenças Crônicas; Sedentarismo.

${ }^{1}$ Universidade Federal do Acre, Rio Branco, Acre, Brazil.

${ }^{2}$ Fundação Oswaldo Cruz, Rio de Janeiro, Rio de Janeiro, Brazil.

${ }^{3}$ Universidade Federal de Uberlândia, Uberlândia, Minas Gerais, Brazil.

${ }^{4}$ Centro Universitário Uninorte, Rio Branco, Acre, Brazil.

Chief Editor: Daniela Chiesa

Associate Editor: Daniela Chiesa

Received on 02/28/20; Accepted on 03/11/21.

Evaluated by double blind review process. 


\section{INTRODUCTION}

Physical activity (PA) has been recognized for centuries as an important contributor to health promotion ${ }^{1-3}$. According to Hippocrates (460-377 BC), a prominent philosopher considered the father of modern medicine and even the first physician to provide a written exercise prescription", "if we could give every individual the right amount of nourishment and exercise, not too little and not too much, we would have found the safest way to health"2. Also, Plato (424-348 BC) said that the "lack of activity destroys every human being's good condition, while movement and methodical physical exercise save it and preserve $i t^{\prime \prime}$. An old Indian medicine book reports that the first definition of physical exercise was recorded around 700 BC as any physical action capable of producing bodily stability and strength'. Nowadays, physical activity (PA) is defined as "any bodily movement produced by skeletal muscles that results in energy expenditure, but does not include the effect of dietinduced thermogenesis"; and physical exercise (PE) as "a subset of PA that is planned, structured, and repetitive and has as a final or an intermediate objective the improvement or maintenance of physical fitness"

The World Health Organization (WHO), which endorsed this concept of physical activity, the Brazilian Society of Sports Medicine and Exercise ${ }^{6}$, and nine more sports medicine societies $^{7}$, have intensively emphasized the importance of PA in health promotion. Physical inactivity is reported as one of the leading causes of disability and mortality ${ }^{8}$, with significant economic $^{9}$ and social ${ }^{10-13}$ impact, making it one of the most urgent health problems of the $21^{\text {st }}$ century 9 . PA plays an essential role in preventing and treating several chronic illnesses ${ }^{14-17}$, mainly noncommunicable diseases $(\mathrm{NCDs})^{18}$. Mortality from these diseases is rapidly increasing worldwide and already accounts for more than half of the global deaths under 70 years of age ${ }^{19}$. In low to middle-income countries, such as Brazil, the risk of premature death from NCDs is 1.5 times higher than in high-income countries ${ }^{20}$. Therefore, it is indisputable that people must be physically active and the governments must apply PA as a public policy ${ }^{9,21}$.

Several studies have shown that medical counseling encourages patients to change behaviors towards healthier lifestyles, and this represents an essential strategy for health promotion ${ }^{7,22-26}$. Besides, the promotion of physical activity in medical education could increase students' advising skills aiming to modify patient behavior ${ }^{27}$. Therefore, physicians and other health professionals should encourage the practice of PA and warn patients about the risk of physical inactivity ${ }^{28}$. These physician-induced behavioral changes in patients' lifestyles should be better accomplished by including PA in the undergraduate institutional curricula or training ${ }^{21,29}$. In this context, in addition to the theoretical knowledge, the medical students' practice of PA might also be a significant additional factor for counseling ${ }^{30,31}$, and might contribute to necessary medical training and not only for the sports medicine specialty ${ }^{7}$.

The existence of static and outdated curricula undermines professional health education considering the constant updating of the global health system and the emergence of new health risks ${ }^{32}$. In recent years, discussions on medical education in Brazil have been stimulated, and they have, in general, emphasized the need to adopt active methodologies as pedagogical strategies ${ }^{33,34}$. Although those discussions point out that the physicians from the $21^{\text {st }}$ century should have transdisciplinary training that allows them to exert multi-professional activities aiming to improve the health problems solutions ${ }^{33}$, no mention of PA among these multiprofessional activities has been reported.

In some countries, PA introduction in medical education has been stimulated ${ }^{35-37}$ to prepare medical students for physical activity counseling to prevent and treat diseases. In Brazil, we still do not have a picture of this situation. Since the need to prepare medical students for physical activity counseling to prevent and treat diseases is a critical one, this study investigates PA topics regarding the Brazilian active medical curricula.

\section{METHODS}

\section{Ethical Aspects}

This study does not require prior approval by an ethics committee since public access to academic curricula is guaranteed by law ${ }^{38}$.

\section{Sample}

A cross-sectional survey was conducted by convenience on two different occasions (April 2015 and February 2019) regarding the curricula of the undergraduate medical courses offered by all Brazilian public and private institutions authorized by the Ministry of Education and Culture (MEC), which regulates and supervises the educational activities in the country.

\section{Data Collection Instruments}

Initial searches were carried out on the MEC website (http://emec.mec.gov.br), focusing on the curricula of undergraduate medical programs currently active in Brazil. No distinctions were made between traditional or nontraditional curricula. All the active curricula listed by MEC have been compiled from educational institution websites. Some institutions have more than one curriculum because they have more than one medical school (on different campuses) or because they have simultaneously two valid active curricula (a new and an old one). 


\section{Data Collection Procedures}

The compiled curricula were randomly divided into three groups. Two independent reviewers analyzed each group regarding the presence of topics on physical activity (PA) in the name of the curricular unit, i.e., subject or thematic module (S/ TM), and/or in its respective syllabus. PA presence as a main or secondary topic within a broader topic in the syllabus was considered an approach to the subject. In case of disagreement between the two researchers examining a curriculum, the study coordinator resolved the dispute. It is essential to note that throughout this study, the term PA refers exclusively to the definition adopted by the $\mathrm{WHO}^{5}$.

\section{Qualitative Data Analysis}

Subsequently, the information was filtered to reduce possible selection biases, and then the data were pooled. The $\mathrm{S} / \mathrm{TM}$ s were classified according to the type of enrollment (mandatory or optional), type of activity (theoretical, practical, or theoretical-practical), and emphasis on the content (health, athletic performance, or health and athletic performance). Therefore, this study consists of documentary research using pre-existing thematic categories.

S/TMs classification concerning the type of enrollment and type of activity was made based on the information collected from each institution's web site. S/TMs with only theoretical activities were considered theoretical; those comprising any practical activity, aiming recreation or training, were considered practical; S/TMs with the simultaneous theoretical and practical activities were considered theoretical-practical.

The S/TMs classification concerning the emphasis (health, performance, or both) was made in an inferential way. The S/TM titled Exercise Physiology: From Normal to Pathological, for example, which was found in one institution located in the state of the São Paulo, has focused on the associations of physical exercise with either cardiac ("acute and chronic effects of physical exercise on the cardiovascular system") or respiratory ("acute and chronic effects of physical exercise on the respiratory system") systems, and this characterizes it as having an emphasis on health. On the other hand, the S/TM Sports Medicine, which was found in another institution in the state of São Paulo, has guidelines for evaluating athletes, among other items, which means that it emphasizes athletic performance. In some situations, the emphasis was on health and athletic performance, as observed with the S/TM Exercise and Sports Medicine, found in one of the institutions in the state of Rio de Janeiro. The excerpts "to develop skills in the evaluation of athletes" and "clinical bases for the prescription of exercise in health and disease" present in its syllabus denotes a concern with both athletic performance and health.

\section{Quantitative Data Analysis}

The present study does not have a sample calculation with a description of statistical power because its objective was to analyze the universe of curricula made available by the institutions.

Data were described as frequency (\%) using Microsoft Excel $^{\mathrm{TM}}$ (Microsoft Corporation, Redmond, WA), and the illustrations were edited using Microsoft PowerPoint ${ }^{\mathrm{TM}}$ (Microsoft Corporation, Redmond, WA).

The subjects or thematic modules with names that indicated the approach to the topic were considered in the frequency calculation. Curricula with unavailable program content of curricular units were excluded from the analysis. However, to minimize sample loss, whenever the necessary information was not available on the institution's website, it was requested from the institution at least twice by phone and/ or e-mail. Only in the absence of a response from the institution, the curriculum was excluded from the analysis. Many of the unavailable curricula at the time of the search were under extinction and being replaced by new curricula, according to the e-MEC website.

A total of 83 (27.1\%) of 306 active curricula in 2015, and 51 (15.1\%) of 337 in 2019 , were not analyzed.

\section{RESULTS}

A total of 223 (72.9\%) of 306 active curricula in 2015, and 286 (84.9\%) of 337 in 2019, were identified. All these curricula were then analyzed regarding disciplines, thematic modules, and even isolated topics on PA.

The selected S/TMs were subsequently classified according to the type of enrollment (mandatory or optional), type of activity (theoretical, practical, or theoretical-practical), and emphasis on the content (health, athletic performance, or health and athletic performance).

The number of S/TMs with PA content in each category was then converted into frequency (\%).

Figure 1 depicts a diagram of the screening of Brazilian medical schools' curricula concerning the frequency of PA contents in their S/TMs, as well as in the classification of these curricular units regarding the type of enrollment (mandatory or optional), type of activity (theoretical, practical or theoretical-practical), and emphasis on the content (health, athletic performance or both) in April 2015 and February 2019.

In 2015, of the 223 analyzed medical schools' curricula, only $24(10.8 \%)$ had at least one S/TM with a topic concerning PA and focused on health or athletic performance and health. In 2019, this number dropped to $19(6.7 \%)$ of 286 analyzed medical schools' curricula. 
Figure 1. Diagram of the screening of Brazilian Medical Schools' curricula concerning the presence of subjects or thematic modules (S/TM) with topics on physical activity (PA) in A) April 2015 and B) February 2019. The S/TM with topics on PA were classified concerning the type of enrollment (mandatory or optional), type of activity (theoretical, practical, or theoreticalpractical), and emphasis on the content (health, athletic performance, or both).

A

\section{Curricula}

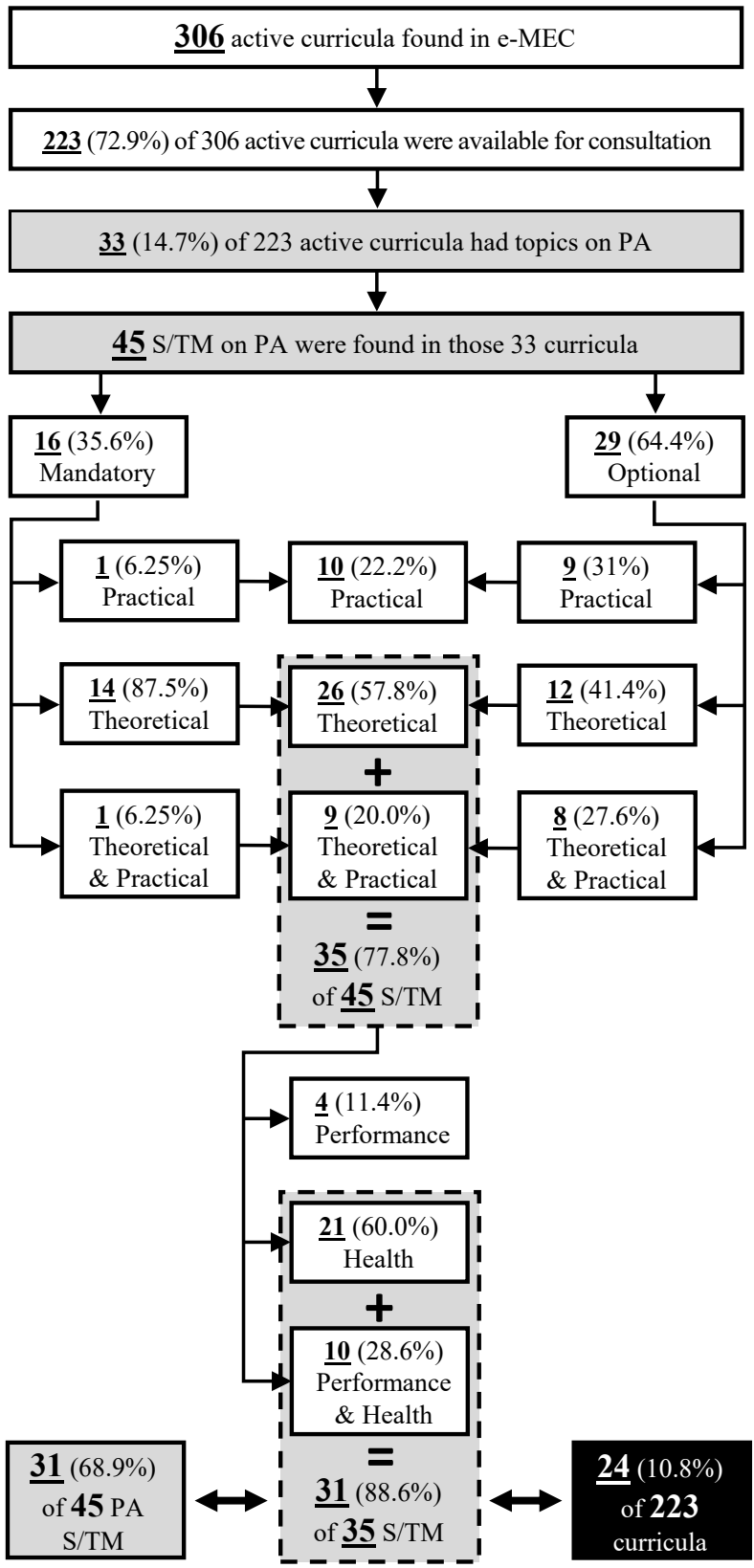

B

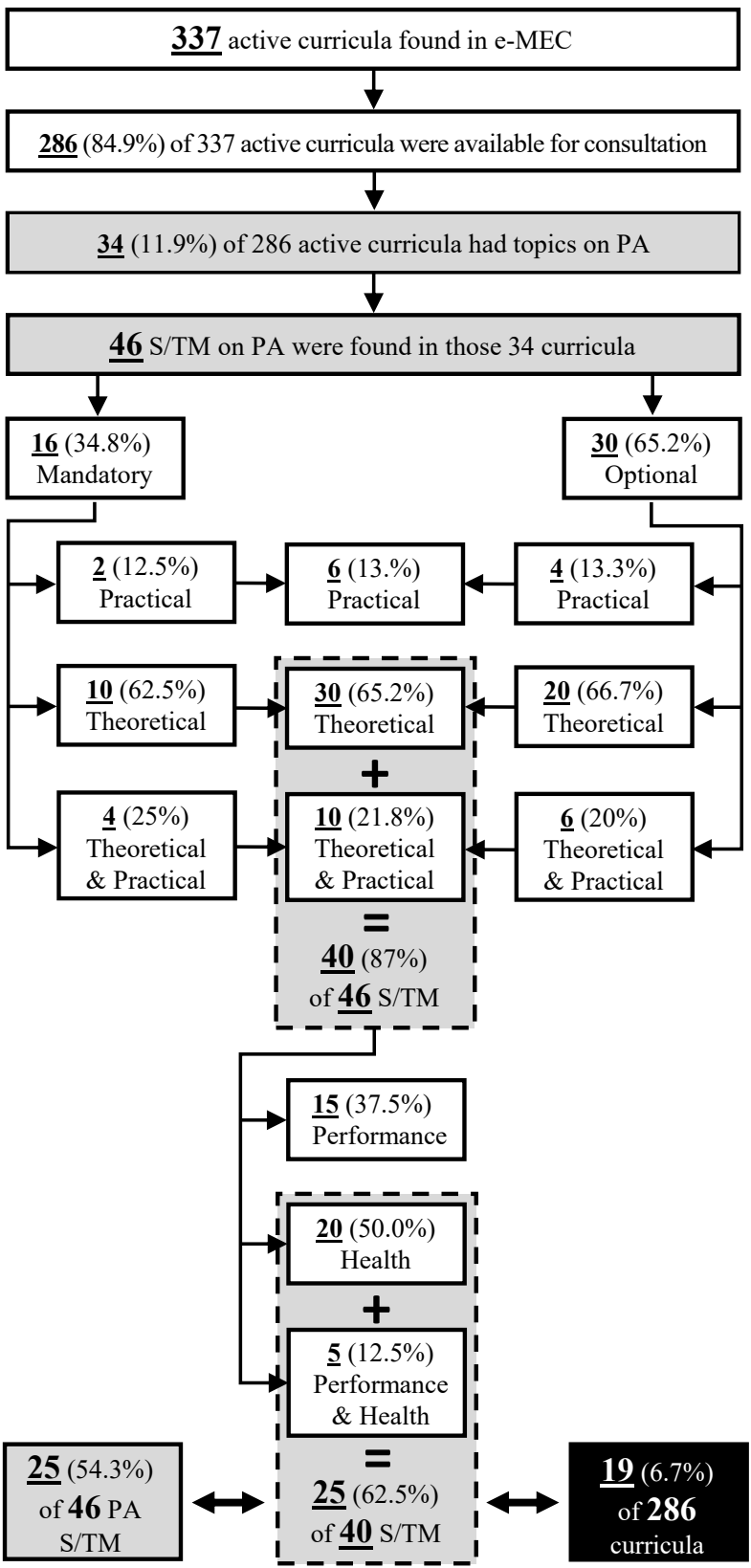

\section{Curricula}

Table 1 and 2 depict the distribution of S/TMs with topics on PA found in medical curricula of Brazilian educational institutions by federation state and also by the type of enrollment (mandatory or optional), type of activity (theoretical, practical or theoretical and practical), and focus (health, performance or health and performance) in 2015 and 2019, respectively.

In 2015, there was only one state (AC) with a mandatory theoretical-practical S/TM with topics focused on the PA benefits for health (Physical Activity in Health Promotion). 
Table 1. Distribution of topics concerning physical activity (PA) found in the medical curricula of Brazilian educational institutions, by Federation state, type of enrollment, approach and emphasis. Brazil, 2015.

\begin{tabular}{|c|c|c|c|c|c|c|c|c|c|}
\hline \multirow[b]{2}{*}{ Subjects/Thematic Modules } & \multirow{2}{*}{$\begin{array}{l}\text { Federation } \\
\text { state }\end{array}$} & \multicolumn{2}{|c|}{ Type of enrollment } & \multicolumn{3}{|c|}{ Type of activity } & \multicolumn{3}{|c|}{ Emphasis } \\
\hline & & Mandatory & Optional & Practical & Theoretical & $\begin{array}{l}\text { Theoretical } \\
\text { \& Practical }\end{array}$ & Performance & Health & Both \\
\hline Physical Activity in Health Promotion II & $A C$ & $\mathrm{x}$ & & & & $\mathrm{x}$ & & $\mathrm{x}$ & \\
\hline Metabolism & AP & $\mathrm{x}$ & & & $\mathrm{x}$ & & & $\mathrm{x}$ & \\
\hline Locomotion & AP & $x$ & & & $x$ & & & $x$ & \\
\hline Locomotion and Prehension & BA & $\mathrm{x}$ & & & $\mathrm{x}$ & & & $\mathrm{x}$ & \\
\hline Sports Medicine & CE & & $\mathrm{x}$ & & & $\mathrm{x}$ & $\mathrm{x}$ & & \\
\hline Sports Practice I & DF & & $\mathrm{x}$ & $\mathrm{x}$ & & & & & \\
\hline Sports Practice II & DF & & $x$ & $x$ & & & & & \\
\hline Sports Medicine & MA & & $\mathrm{x}$ & & $\mathrm{x}$ & & $\mathrm{x}$ & & \\
\hline Sport Physiology & MG & & $x$ & & $x$ & & & & $x$ \\
\hline Sports Medicine & MG & & $x$ & & $x$ & & & & $x$ \\
\hline Aging and Physical Activity & MG & & $\mathrm{x}$ & & $\mathrm{x}$ & & & $\mathrm{x}$ & \\
\hline Locomotion and Prehension & MG & $x$ & & & $x$ & & & $x$ & \\
\hline Biological Basis of Medical Practice & MG & $x$ & & & $x$ & & & $x$ & \\
\hline $\begin{array}{l}\text { Musculoskeletal System: Skin and } \\
\text { Attachments }\end{array}$ & MG & $\mathrm{x}$ & & & $\mathrm{x}$ & & & $x$ & \\
\hline Geriatrics & MG & $x$ & & & $\mathrm{x}$ & & & $\mathrm{x}$ & \\
\hline Clinical Exercise Physiology & MG & & $x$ & & $x$ & & & $x$ & \\
\hline Sports Practice I & MG & & $x$ & $x$ & & & & & \\
\hline Sports Practice II & MG & & $\mathrm{x}$ & $\mathrm{x}$ & & & & & \\
\hline Biological Functions & PA & $\mathrm{x}$ & & & $\mathrm{x}$ & & & $\mathrm{x}$ & \\
\hline Metabolism and Nutrition & PA & $x$ & & & $x$ & & & $x$ & \\
\hline Sports and Exercise Medicine & $\mathrm{PE}$ & & $\mathrm{x}$ & & & $\mathrm{x}$ & $\mathrm{x}$ & & \\
\hline Medicine for the Elderly & $P E$ & $\mathrm{x}$ & & & $\mathrm{x}$ & & & $\mathrm{x}$ & \\
\hline Sports and Exercise Medicine & $\mathrm{PE}$ & & $\mathrm{x}$ & & & $\mathrm{x}$ & & & $\mathrm{x}$ \\
\hline $\begin{array}{l}\text { Culture, Sports, Interpersonal Relations, } \\
\text { Humanization }\end{array}$ & $\mathrm{PE}$ & $\mathrm{x}$ & & & $\mathrm{x}$ & & & & $\mathrm{x}$ \\
\hline Locomotion and Prehension & PR & $\mathrm{x}$ & & & $\mathrm{x}$ & & & $\mathrm{x}$ & \\
\hline Sports Medicine & PR & & $x$ & & & $x$ & & & $x$ \\
\hline Exercise and Sports Medicine & RJ & & $\mathrm{x}$ & & & $\mathrm{x}$ & & & $\mathrm{x}$ \\
\hline Exercise and Sports Medicine & $\mathrm{RJ}$ & & $\mathrm{x}$ & & $x$ & & & $x$ & \\
\hline Exercise and Sports Medicine & $\mathrm{RJ}$ & & $x$ & & $x$ & & & $x$ & \\
\hline Musculoskeletal system & RJ & $\mathrm{x}$ & & & $x$ & & & $x$ & \\
\hline Exercise Physiology & RJ & & $\mathrm{x}$ & & $\mathrm{x}$ & & & & $\mathrm{x}$ \\
\hline Exercise and Sports Medicine & RJ & & $\mathrm{x}$ & & & $\mathrm{x}$ & & & $\mathrm{x}$ \\
\hline $\begin{array}{l}\text { Physical Activity, Health and Quality } \\
\text { of Life }\end{array}$ & RN & & $x$ & & & $x$ & & & $x$ \\
\hline Physical Activity, Leisure and Culture & RN & & $\mathrm{x}$ & & & $x$ & & $\mathrm{x}$ & \\
\hline Sports Practice I & RN & & $x$ & $x$ & & & & & \\
\hline Sports Practice II & RN & & $x$ & $\mathrm{x}$ & & & & & \\
\hline Sports Practice I & RN & & $\mathrm{x}$ & $\mathrm{x}$ & & & & & \\
\hline Sports Practice II & RN & & $\mathrm{x}$ & $\mathrm{x}$ & & & & & \\
\hline Physical Activity and Health & RS & $\mathrm{x}$ & & & $\mathrm{x}$ & & & $\mathrm{x}$ & \\
\hline Sports Medicine & SP & & $\mathrm{x}$ & & $\mathrm{x}$ & & & & $\mathrm{x}$ \\
\hline Physical Education & SP & $\mathrm{x}$ & & $\mathrm{x}$ & & & & & \\
\hline Sports Medicine & SP & & $\mathrm{x}$ & & $\mathrm{x}$ & & $\mathrm{x}$ & & \\
\hline $\begin{array}{l}\text { Exercise Physiology: From Normal to } \\
\text { Pathological }\end{array}$ & SP & & $x$ & & $x$ & & & $x$ & \\
\hline
\end{tabular}


Table 1. (Continuation) Distribution of topics concerning physical activity (PA) found in the medical curricula of Brazilian educational institutions, by Federation state, type of enrollment, approach and emphasis. Brazil, 2015.

\begin{tabular}{|c|c|c|c|c|c|c|c|c|c|}
\hline \multirow{2}{*}{ Subjects/Thematic Modules } & \multirow{2}{*}{$\begin{array}{l}\text { Federation } \\
\text { state }\end{array}$} & \multicolumn{2}{|c|}{ Type of enrollment } & \multicolumn{3}{|c|}{ Type of activity } & \multicolumn{3}{|c|}{ Emphasis } \\
\hline & & Mandatory & Optional & Practical & Theoretical & $\begin{array}{l}\text { Theoretical } \\
\text { \& Practical }\end{array}$ & Performance & Health & Both \\
\hline $\begin{array}{l}\text { Exercise Physiology: From Normal to } \\
\text { Pathological }\end{array}$ & SP & & $\mathrm{x}$ & & $X$ & & & $x$ & \\
\hline Physical Education & SP & & $x$ & $x$ & & & & & \\
\hline Total & - & 16 & 29 & 10 & 26 & 9 & 4 & 21 & 10 \\
\hline
\end{tabular}

Abbreviations: AC, Acre; AP, Amapá; BA, Bahia; CE, Ceará; DF, Distrito Federal; MA, Maranhão; MG, Minas Gerais; PA, Pará; PE, Pernambuco; PR, Paraná; RJ, Rio de Janeiro; RN, Rio Grande do Norte; SP, São Paulo.

Table 2. Distribution of topics concerning physical activity (PA) found in medical curricula of Brazilian educational institutions, by Federation State, type of enrollment, approach and emphasis. Brazil, 2019.

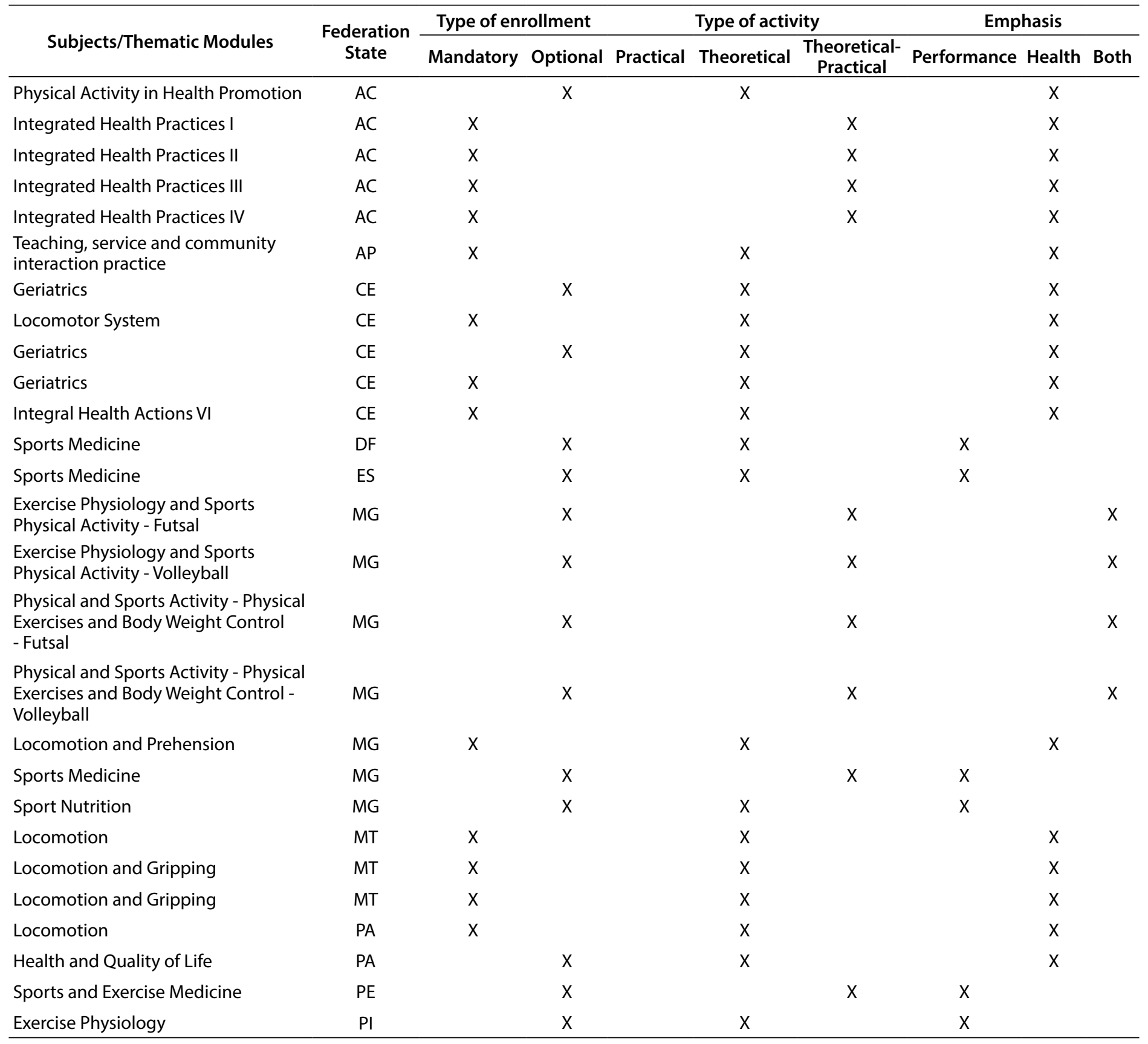


Table 2. (Continuation) Distribution of topics concerning physical activity (PA) found in medical curricula of Brazilian educational institutions, by Federation State, type of enrollment, approach and emphasis. Brazil, 2019.

\begin{tabular}{|c|c|c|c|c|c|c|c|c|c|}
\hline Subjects/Thematic Modules & $\begin{array}{c}\text { Federation } \\
\text { State }\end{array}$ & \multicolumn{2}{|c|}{ Type of enrollment } & \multicolumn{3}{|c|}{ Type of activity } & \multicolumn{3}{|c|}{ Emphasis } \\
\hline $\begin{array}{l}\text { Exercise Physiology and Sports } \\
\text { Medicine }\end{array}$ & PR & & $x$ & & $x$ & & $\mathrm{x}$ & & \\
\hline Sports Practice & PR & & $x$ & $x$ & & & & & \\
\hline Sports Medicine & PR & & $\mathrm{x}$ & & $x$ & & $x$ & & \\
\hline Sports Medicine & RJ & & $x$ & & $x$ & & $x$ & & \\
\hline Physical Exercise Physiology & RJ & & $x$ & & $x$ & & $\mathrm{x}$ & & \\
\hline Exercise and Sports Medicine & RJ & & $x$ & & $x$ & & $x$ & & \\
\hline Sports Practices I & $\mathrm{RN}$ & & $x$ & $x$ & & & & & \\
\hline Sports Practices II & $\mathrm{RN}$ & & $x$ & $x$ & & & & & \\
\hline Sports Traumatology & RO & & $x$ & & $x$ & & $\mathrm{x}$ & & \\
\hline Physical Education - Sports Practice I & SC & $x$ & & $x$ & & & & & \\
\hline Physical Education - Sports Practice II & SC & $x$ & & $\mathrm{x}$ & & & & & \\
\hline Introduction to Sports Medicine & $\mathrm{SP}$ & & $x$ & & $x$ & & $x$ & & \\
\hline $\begin{array}{l}\text { Exercise Physiology Applied to the } \\
\text { Medical Clinic }\end{array}$ & SP & & $\mathrm{X}$ & & $\mathrm{x}$ & & & $x$ & \\
\hline $\begin{array}{l}\text { Exercise Physiology Applied to the } \\
\text { Medical Clinic }\end{array}$ & SP & & $x$ & & $x$ & & & $x$ & \\
\hline Physical Activity and Health & SP & $x$ & & & $x$ & & & $x$ & \\
\hline
\end{tabular}

Abbreviations: AC, Acre; AP, Amapá; CE, Ceará; DF, Distrito Federal; ES, Espírito Santo; MG, Minas Gerais; MT, Mato Grosso; PA, Pará; PE, Pernambuco; PI, Piauí; PR, Paraná; RJ, Rio de Janeiro; RN, Rio Grande do Norte; SP, São Paulo.

Overall, the 2019 search showed that when S/TMs containing topics on physical activity were mandatory, PA was only a small part of a broad administered content (e.g., Geriatrics, Locomotion, Integrated Health Practices, among others).

There were some S/TMs (e.g., Exercise and Sports Medicine, in Table 1; Geriatrics, in Table 2) that appeared twice or more in only one federation state because they belong to different medical curricula.

\section{DISCUSSION}

To the best of our knowledge, this is the first study that investigated the presence of PA topics in the Brazilian medical schools' curricula. Since regular physical exercise is widely known to bring people many health benefits ${ }^{17,39-42}$, in addition to reducing health care expenses ${ }^{43-45}$, this study brings evidence that Brazilian physicians are not being prepared to consciously participate in the prophylactic and therapeutical use of physical activity. The supporting evidence is the scarcity of topics on physical activity in Brazilian medical curricula (Figure 1).
The reduction between 2015 and 2019 in the absolute number of curricular units that address PA in Brazilian medical curricula (Figure 1) sounds alarming and unsustainable in all possible aspects, given the need to improve quality, competence, efficiency, and reduction of public health costs, especially in a society where the physician plays an essential role in the health-promoting process. This curricular gap means that neither medical schools nor the Government are fully exercising their roles. Medical schools must comply with principles of ethical commitment and social relevance to implement, in the face of public policies for education, the necessary changes to adapt undergraduate medicine curricula to the demand for quality health services for the population ${ }^{33}$. It is worth mentioning that this reduction in curricular units that address PA occurs in the context of an increase in chronic diseases and their risk factors in Brazil ${ }^{46}$, which is absolutely unjustifiable, since physical exercise is one of the greatest allies in the prevention and control of these diseases ${ }^{47,48}$.

About one-third of the world population is physically 
inactive ${ }^{49}$ and overweight, and obesity rates are alarming and have been increasing over the years ${ }^{50}$. In Brazil, $41.2 \%$ of men and $50.4 \%$ of women are physically inactive ${ }^{51}$. It is a consensus among experts that PA itself contributes substantially to health promotion. Up to $80 \%$ of coronary heart disease, $90 \%$ of type 2 diabetes, and one-third of cancers can be prevented by healthy habits, maintaining a desirable weight, and regular physical activity $^{52}$. Also, at least 13 different cancer types show a risk reduction by leisure-time physical activity practice ${ }^{53}$. Physical activity contributes to the regulation of the immunological system and reduces systemic chronic inflammation ${ }^{17,40,41}$, which is the leading cause of comorbidities and death worldwide ${ }^{17}$.

As mentioned before, increasing the practice of PA has become an important global issue. Physical inactivity is one of the leading causes of disability and mortality ${ }^{8}$, with great economic $^{9,45}$, and social ${ }^{10-13}$ impacts, making it one of the most urgent health problems of the $21^{\text {st }}$ century ${ }^{9}$. Therefore, PA should be prioritized worldwide as part of a comprehensive strategy to reduce illnesses, especially the NCDs ${ }^{17,45}$. In this context, recently, Arocha Rodulfo suggested that a sedentary lifestyle should be considered a disease ${ }^{54}$. This suggestion makes sense. Muscles work as an endocrine gland ${ }^{55}$ and can interfere in all human systems ${ }^{17,39}$. In turn, PA is essential to modulate muscle epigenetics ${ }^{56}$, promoting the release of thousands of proteins into the bloodstream ${ }^{57}$.

We observed that pharmacology contents appear as mandatory during the curricula evaluation, without exceptions. This observation contrasts with the presence of PA topic, which occurs in medical curricula as an exception and not a rule. However, PA may behave as a medication ${ }^{2,14,39,58}$ in many cases, with actions comparable to or even superior to drug interventions ${ }^{14}$. While some medications used to treat the most common conditions, such as NCDs, may increase the risk of other diseases ${ }^{59-63}$, PA may even modulate the immune system, contributing to the prevention and/or treatment of several illnesses ${ }^{40,41}$, and increase longevity ${ }^{64}$. This action of PA is why the pharmaceutical industry has been searching for pharmacological agents that can mimic the benefits of exercise, the "exercise pill"65. A change in the disease-drug paradigm involves medical education, since the physician is the health professional who exerts the most significant influence on the population ${ }^{29}$.

The incorporation of lifestyle medicine in medical education has already been proposed ${ }^{21,66,67}$. Lifestyle medicine is the evidence-based practice committed to helping individuals and families to adopt and sustain behaviors that promote health and improve quality of life. These healthy behaviors include but are not limited to eliminating tobacco use, improving diet, increasing physical activity, and moderating alcohol consumption $^{66}$. The need to include topics on PA, nutrition, personal care, and behavior changes in a topic called 'Lifestyle Medicine' in both the undergraduate medical curriculum and all continuing medical education levels is fundamental. PA should be present in longitudinal, transversal, and interdisciplinary discussions on the prevention and/or therapeutics of chronic degenerative diseases ${ }^{21,68}$.

The promotion of physical activity in medical education requires that undergraduate medical programs increase the students' awareness about PA's benefits for their health and develop counseling skills to modify patient behavior ${ }^{27}$. Indeed, a robust dose-effect relationship exists between the volume of leisure-time PA and medical students' quality of life ${ }^{69}$. Physicians who do not practice PA and have a body mass index (BMI) above the reference range considered normal do not feel confident recommending PA to their patients ${ }^{70}$. Additionally, physicians engaged in a physical exercise routine feel more confident and more prone to recommend exercise practice during the consultation ${ }^{70,71}$.

The students and physicians' lack of knowledge and confidence seems to be the worldwide reality. An informal survey of sports and exercise medicine practitioners suggested no significant teaching of sports and exercise medicine in the core medical curricula in Australia, Canada, Greece, Italy, the Netherlands, New Zealand, South Africa, or the USA ${ }^{72}$. The world situation does not seem to be so different from the situation described in the present Brazilian study.

Although many US medical schools report providing some PA content, the time dedicated to this topic is still lower than that dedicated to other topics, such as nutrition education ${ }^{35}$.

In Australia, most medical schools reported the inclusion of some physical training in their medical curricula. However, key topics, such as the national strength training recommendations, is not taught in most schools in Australia ${ }^{36}$.

In the United Kingdom (UK), sports and exercise medicine in the undergraduate medical curriculum was proposed almost forty years ago $^{73}$. In a 2011 survey about the UK medical undergraduate curricula, in 25 of 33 medical schools that answered the survey, $100 \%$ included musculoskeletal medicine, $68 \%$ included exercise and obesity, and only $40 \%$ included sports and exercise medicine ${ }^{74}$. However, many studies describe a lack of coverage of this topic in the UK medical curricula ${ }^{72,74-77}$. A 2013 study aiming to assess final-year medical students' knowledge about the physical inactivity risks and their confidence in recommending PA concluded that the medical students do not have the necessary knowledge and skills to recommend PA to their patients, thus indicating the need for more solid medical training in this regard ${ }^{37}$. In a more recent study carried out at 22 UK medical schools, students had insufficient knowledge of the UK Chief Medical Officer's Guidelines for adult physical 
activity, low confidence in counseling, and a tendency to better recognize the importance of exercise aimed at prevention but not for disease management, which reinforces the need to promote knowledge of the benefits of PA not only for the prevention of NCDs but also for its management ${ }^{78}$.

Given PA's relevance for the prevention and treatment of many physical and mental diseases, it is unlikely that the attention it currently receives is sufficient to prepare medical students for their professional performance. As Jaques and Loosemore asked, "Why is PA medicine not adequately included in the undergraduate curriculum"72? Impediments include lack of curricular space, time, and qualified educators ${ }^{75-77,79}$. Expansion of curricular units and secondary care clinicians' education is part of the solutions for these impediments, besides the teaching of physical activity ${ }^{37}$. Multiagency coordination involving government departments and undergraduate and postgraduate curriculum leads is also needed ${ }^{37}$. Moreover, innovative ideas are needed to integrate greater quantity with better quality in PA use to train the next generations of physicians ${ }^{35}$.

Although the family doctor, who congregates preventive and personal health services ${ }^{80}$, has been identified by the community as the preferred PA information source among all health professionals ${ }^{81}$, medical education involves adequate training on the topic, regardless of professional specialization. In this aspect, the use of active methodologies to study the importance of physical activity in health promotion and treatment of diseases can be an innovative and an appropriate pedagogical strategy for medical education in this area of knowledge.

In Brazil, the National Curricular Guidelines for undergraduate medical courses cover health promotion and prevention practices, including $\mathrm{PA}^{82}$. However, the curricula do not show whether - and certainly not when and how - PA is addressed, as shown by this study, bringing great uncertainty regarding the debate on a necessary and urgent topic for future doctors. It is essential that the inclusion of PA in curricula be programmed and take place in different contexts, not only from a biological point of view or by a specific medical area - as this would probably lead to purely prescriptive and decontextualized guidance - but also from a perspective of salutogenesis, with an approach aimed at changing the population's lifestyle. In this context, tools that contribute to a better doctor-patient relationship through adequate communication, such as motivational interview ${ }^{83}$ and patientcentered medicine ${ }^{84}$, are of great importance in the lifestyle change process, and therefore, the debate on PA should be included along with such tools.

It is a fact that PA is seen as part of other topics in medical schools and can be worked on within various curricular units. However, considering the findings of the present study and the raised discussions, it is essential that the approach be explicit and programmed in the medical curricula, not necessarily as a curricular unit, but longitudinally during the course and, ideally in conjunction with other discussions, aimed at both disease prevention and treatment. The mere presence of PA in the syllabus of mandatory curricular units can be an initial step to guarantee its adequate inclusion in medical education.

\section{Strengths and limitations}

The greatest strength of the present study is its pioneering characteristic, since this is the first study on the proposed topic carried out in the country. Another strength is its proposal to analyze all pedagogical programs of medical courses in the country. Since the study effectively analyzed $72.9 \%$ (in 2015) and $84.9 \%$ (in 2019) of the undergraduate medical curricula in Brazil, the points addressed herein represent the overall situation of Brazilian medical education regarding physical activity for health promotion.

It is essential to highlight that the unavailability of the medical schools' curricula at the institutions' websites totaling 27\% (83/306) in 2015 and 15.1\% (51/337) in 2019 does not represent a study limitation but constitutes a severe transgression by the institutions, since Brazilian law determines that universities and colleges must publish and keep up to date the curricula and curricular components of their courses on specific internet pages ${ }^{38}$.

One of the study limitations was not identifying curricular units that work with PA within broader topics and that do not necessarily contain the term PA in its name. Moreover, some of the accessed institutional documents were very succinct and did not allow an in-depth analysis of how PA was effectively addressed in its program.

\section{CONCLUSION}

The presence of curricular units with contents on physical activity in only $10.8 \%$ of the investigated curricula in 2015 and $6.7 \%$ in 2019 should serve as a warning for the medical education institutions about the need of reviewing their curricula to better prepare future physicians for the task of facing the practice of physical activities for their health, as well as to advising patients on the role of physical activity in disease prevention and treatment. The economic and social burden of physical inactivity enforces this need.

The inclusion of longitudinally distributed PA contents in medical curricula would include a mandatory type of enrollment, theoretical and if possible - practical approaches, and emphasis on health promotion and treatment of diseases. In addition to contributing to their health promotion, these changes can promote the engagement of the trained professionals during 
their lifetime, which is desirable, since those physicians who are engaged in a physical activity routine feel more confident and more prone to advising the practice of exercise to their patients.

\section{ACKNOWLEDGMENTS}

The authors would like to thank the researchers Bianca Oliveira Aymores, Douglas Duarte Pereira, Alan José Santana, Márcia Rejane Sordi Bortolini, Aníbal Monteiro de Magalhães Neto, Luís Eduardo Maggi, José Renan da Cunha Melo and Romeu Paulo Martins Silva, for their contributions in the development of this study.

\section{AUTHORS' CONTRIBUTION}

Miguel Junior Sordi Bortolini and Cristiane Soares Ferreira Bortolini planned the study. Cristiane Soares Ferreira Bortolini, Amanda Capeloto Mastro, Gabriel Marcos Barbosa and Luciana Alves de Medeiros were responsible for the data collection and data curation. Descriptive statistics were made by Miguel Junior Sordi Bortoloni and Nilson Penha-Silva. All authors contributed equally in the preparation of original draft of the manuscript. Miguel Junior Sordi Bortolini, Nilson Penha-Silva and Luciana Alves de Medeiros prepared the final edition of the manuscript.

\section{CONFLICTS OF INTEREST}

The authors state that they have no conflicts of interest to declare.

\section{SOURCES OF FUNDING}

None.

\section{REFERENCES}

1. Sharma RK, Dash B. Caraka Samhita. Varanasi, India: Chowkhamba Sanskrit Bhawan; 2008.

2. Buford TW, Roberts MD, Church TS. Toward exercise as personalized medicine. Sports Med. 2013;43(3):157-65.

3. Fox SM, 3rd, Haskell WL. Physical activity and the prevention of coronary heart disease. Bull NY Acad Med. 1968;44(8):950-67.

4. Tipton CM. The history of "Exercise Is Medicine" in ancient civilizations. Adv Physiol Educ. 2014;38(2):109-17.

5. Caspersen CJ, Powell KE, Christenson GM. Physical activity, exercise, and physical fitness: definitions and distinctions for health-related research. Public Health Rep. 1985;100(2):126-31.

6. Blair SN, Bouchard C, Gyarfas I, Hollmann W, Iwane H, Knuttgen HG, et al. Exercício para a saúde. Rev Bras Med Esporte. 1998;4:120-1.

7. Thornton JS, Fremont P, Khan K, Poirier P, Fowles J, Wells GD, et al. Physical activity prescription: a critical opportunity to address a modifiable risk factor for the prevention and management of chronic disease: a position statement by the Canadian Academy of Sport and Exercise Medicine. Br J Sports Med. 2016;50(18):1109-14.

8. O'Reilly D, Gaebel K, Xie F, Tarride JE, Goeree R. Health economic evaluations help inform payers of the best use of scarce health care resources. Int J Circumpolar Health. 2011;70(4):417-27.
9. Davis JC, Verhagen E, Bryan S, Liu-Ambrose T, Borland J, Buchner D, et al. 2014 consensus statement from the first Economics of Physical Inactivity Consensus (EPIC) conference (Vancouver). Br J Sports Med 2014:48(12):947-51.

10. Seipel MM, Shafer K. The effect of prenatal and postnatal care on childhood obesity. Soc Work. 2013;58(3):241-52.

11. Zomer AC, Vaartjes I, Uiterwaal CS, van der Velde ET, Sieswerda GJ, Wajon $E M$, et al. Social burden and lifestyle in adults with congenital heart disease. Am J Cardiol. 2012;109(11):1657-63.

12. Lee $\mathrm{DH}$. Persistent organic pollutants and obesity-related metabolic dysfunction: focusing on type 2 diabetes. Epidemiol Health. 2012;34:e2012002.

13. Zhang L, Zhang WH, Wang PY. Prevalence of overweight/obesity and its associations with hypertension, diabetes, dyslipidemia, and metabolic syndrome: a survey in the suburban area of Beijing, 2007. Obes Facts. 2011;4(4):284-9.

14. Naci $\mathrm{H}$, loannidis JP. Comparative effectiveness of exercise and drug interventions on mortality outcomes: metaepidemiological study. BMJ. 2013:347:f5577.

15. Barnes PM, Schoenborn CA. Trends in adults receiving a recommendation for exercise or other physical activity from a physician or other health professional. NCHS Data Brief. 2012(86):1-8.

16. Minich DM, Bland JS. Personalized lifestyle medicine: relevance for nutrition and lifestyle recommendations. Scientific World Journal 2013;2013:129841.

17. Furman D, Campisi J, Verdin E, Carrera-Bastos P, Targ S, Franceschi C, et al. Chronic inflammation in the etiology of disease across the life span. Nat Med. 2019;25(12):1822-32.

18. Rezende LFM, Garcia LMT, Mielke GI, Lee DH, Giovannucci E, ElufNeto J. Physical activity and preventable premature deaths from noncommunicable diseases in Brazil.J Public Health (Oxf). 2019;41(3):e253-e60.

19. WHO. Global Status Report on Noncommunicable Diseases. Geneva: WHO Press; 2014.

20. Allen L, Cobiac L, Townsend N. Quantifying the global distribution of premature mortality from non-communicable diseases. J Public Health (Oxf). 2017;39(4):698-703.

21. Trilk J, Nelson L, Briggs A, Muscato D. Including Lifestyle Medicine in Medical Education: Rationale for American College of Preventive Medicine/American Medical Association Resolution 959. Am J Prev Med. 2019;56(5):e169-e75.

22. Ribeiro MA, Martins MA, Carvalho CRF. The role of physician counseling in improving adherence to physical activity among the general population. Sao Paulo Med J. 2007;125:115-21.

23. Jay M, Gillespie C, Schlair S, Sherman S, Kalet A. Physicians' use of the 5As in counseling obese patients: is the quality of counseling associated with patients' motivation and intention to lose weight? BMC Health Serv Res. 2010;10:159.

24. Kant AK, Miner P. Physician advice about being overweight: association with self-reported weight loss, dietary, and physical activity behaviors of US adolescents in the National Health and Nutrition Examination Survey, 1999-2002. Pediatrics. 2007;119(1):e142-7.

25. Greenlund KJ, Giles WH, Keenan NL, Croft JB, Mensah GA. Physician advice, patient actions, and health-related quality of life in secondary prevention of stroke through diet and exercise. Stroke. 2002;33(2):565-70.

26. Lobelo F, Rohm Young D, Sallis R, Garber MD, Billinger SA, Duperly J, et al. Routine Assessment and Promotion of Physical Activity in Healthcare Settings: A Scientific Statement From the American Heart Association. Circulation. 2018;137(18):e495-e522.

27. Angyan L. Promoting physical activity in medical education. Mini-review. Acta Physiol Hung. 2004;91(2):157-66.

28. Sallis R. Exercise is medicine: a call to action for physicians to assess and prescribe exercise. Phys Sportsmed. 2015;43(1):22-6. 
29. Munstedt K, Vogt T, Rabanus ME, Hubner J. Wishes and beliefs of cancer patients regarding counseling on integrative medicine. Breast Care (Basel). 2014;9(6):416-20.

30. Oberg EB, Frank E. Physicians' health practices strongly influence patient health practices. J R Coll Physicians Edinb. 2009;39(4):290-1.

31. Frank E, Breyan J, Elon L. Physician disclosure of healthy personal behaviors improves credibility and ability to motivate. Arch Fam Med. 2000;9(3):287-90

32. Frenk J, Chen L, Bhutta ZA, Cohen J, Crisp N, Evans T, et al. Health professionals for a new century: transforming education to strengthen health systems in an interdependent world. Lancet. 2010;376(9756):1923-58

33. Lampert JB. Tendências de mudanças na formação médica no Brasil: tipologia das escolas. São Paulo: Hucitec; 2009. 305 p.

34. Gomes R, Brino RF, Aquilante AG, Avó LRS. Aprendizagem Baseada em Problemas na formação médica e o currículo tradicional de Medicina: uma revisão bibliográfica. Rev Bras Educ Med. 2009;33:433-40.

35. Stoutenberg M, Stasi S, Stamatakis E, Danek D, Dufour T, Trilk JL, et al. Physical activity training in US medical schools: Preparing future physicians to engage in primary prevention. Phys Sportsmed. 2015;43(4):388-94.

36. Strong A, Stoutenberg $M$, Hobson-Powell A, Hargreaves $M$, Beeler $H$, Stamatakis E. An evaluation of physical activity training in Australian medical school curricula. J Sci Med Sport. 2017;20(6):534-8.

37. Dunlop M, Murray AD. Major limitations in knowledge of physical activity guidelines among UK medical students revealed: implications for the undergraduate medical curriculum. Br J Sports Med. 2013;47(11):718-20.

38. Brasil. Presidência da República. Lei № 13.168, de 6 de outubro de 2015. Altera a redação do $\S 1^{\circ}$ do art. 47 da Lei no 9.394 , de 20 de dezembro de 1996 - Lei de Diretrizes e Bases da Educação Nacional, (2015).

39. Fiuza-Luces C, Garatachea N, Berger NA, Lucia A. Exercise is the real polypill. Physiology (Bethesda). 2013;28(5):330-58.

40. Walsh NP, Gleeson M, Pyne DB, Nieman DC, Dhabhar FS, Shephard RJ, et al. Position statement. Part two: Maintaining immune health. Exerc Immunol Rev. 2011;17:64-103.

41. Walsh NP, Gleeson M, Shephard RJ, Woods JA, Bishop NC, Fleshner M, et al. Position statement. Part one: Immune function and exercise. Exerc Immunol Rev. 2011;17:6-63.

42. Bortolini MJ, Reis IT, Mineo JR. Open letter to all authorities and institutions involved in managing curricula of physical education in Brazil. Exerc Immunol Rev. 2013;19:164-5.

43. Hambrecht R, Walther C, Mobius-Winkler S, Gielen S, Linke A, Conradi K, et al. Percutaneous coronary angioplasty compared with exercise training in patients with stable coronary artery disease: a randomized trial. Circulation. 2004;109(11):1371-8.

44. United Kingdon. Chief Medical Officer. On the state of the public health Annual report of the chief medical officer 2009. 2010.

45. Ding $\mathrm{D}$, Lawson $\mathrm{KD}$, Kolbe-Alexander $\mathrm{TL}$, Finkelstein EA, Katzmarzyk PT, van Mechelen W, et al. The economic burden of physical inactivity: a global analysis of major non-communicable diseases. Lancet. 2016;388(10051):1311-24

46. Cohen RV, Drager LF, Petry TBZ, Santos RD. Metabolic health in Brazil: trends and challenges. Lancet Diabetes Endocrinol. 2020;8(12):937-8.

47. Anderson E, Durstine JL. Physical activity, exercise, and chronic diseases: A brief review. Sports Medicine and Health Science. 2019;1(1):3-10.

48. Durstine JL, Gordon B, Wang Z, Luo X. Chronic disease and the link to physical activity. Journal of Sport and Health Science. 2013;2(1):3-11.

49. Hallal PC, Andersen LB, Bull FC, Guthold R, Haskell W, Ekelund U. Global physical activity levels: surveillance progress, pitfalls, and prospects. Lancet. 2012;380(9838):247-57.

50. NCD Risk Factor Collaboration (NCD-RisC). Trends in adult body-mass index in 200 countries from 1975 to 2014: a pooled analysis of 1698 population-based measurement studies with 19.2 million participants. Lancet. 2016;387(10026):1377-96.
51. Brasil. Ministério do Esporte. DIESPORTE - Diagnóstico Nacional do Esporte: Caderno 1. Brasília: Ministério do Esporte; 2015.

52. Nishida C, Uauy R, Kumanyika S, Shetty P. The joint WHO/FAO expert consultation on diet, nutrition and the prevention of chronic diseases: process, product and policy implications. Public Health Nutr. 2004;7(1A):245-50.

53. Moore SC, Lee IM, Weiderpass E, Campbell PT, Sampson JN, Kitahara CM et al. Association of Leisure-Time Physical Activity With Risk of 26 Types of Cancer in 1.44 Million Adults. JAMA Intern Med. 2016;176(6):816-25.

54. Rodulfo JIA. Sedentary lifestyle a disease from xxi century. Clin Investig Arterioscler. 2019;31(5):233-40.

55. Pedersen BK, Febbraio MA. Muscle as an endocrine organ: focus on muscle-derived interleukin-6. Physiol Rev. 2008;88(4):1379-406

56. McGee SL, Hargreaves M. Epigenetics and Exercise. Trends Endocrinol Metab. 2019;30(9):636-45.

57. Whitham M, Febbraio MA. The ever-expanding myokinome: discovery challenges and therapeutic implications. Nat Rev Drug Discov. 2016;15(10):719-29.

58. Vina J, Sanchis-Gomar F, Martinez-Bello V, Gomez-Cabrera MC. Exercise acts as a drug; the pharmacological benefits of exercise. $\mathrm{Br} J$ Pharmacol. 2012;167(1):1-12.

59. Andrzejewski S, Gravel SP, Pollak M, St-Pierre J. Metformin directly acts on mitochondria to alter cellular bioenergetics. Cancer Metab. 2014;2:12.

60. Bernstein KE, Khan Z, Giani JF, Cao DY, Bernstein EA, Shen XZ. Angiotensinconverting enzyme in innate and adaptive immunity. Nat Rev Nephrol. 2018;14(5):325-36.

61. Holper L, Ben-Shachar D, Mann JJ. Multivariate meta-analyses of mitochondrial complex I and IV in major depressive disorder, bipolar disorder, schizophrenia, Alzheimer disease, and Parkinson disease. Neuropsychopharmacology. 2019;44(5):837-49.

62. Laudisio A, Incalzi RA, Gemma A, Giovannini S, Lo Monaco MR, Vetrano $\mathrm{DL}$, et al. Use of proton-pump inhibitors is associated with depression: a population-based study. Int Psychogeriatr. 2018;30(1):153-9.

63. Lovell AR, Ernst ME. Drug-Induced Hypertension: Focus on Mechanisms and Management. Curr Hypertens Rep. 2017;19(5):39.

64. Turner JE. Is immunosenescence influenced by our lifetime "dose" of exercise? Biogerontology. 2016;17(3):581-602.

65. Vina J, Borras C, Sanchis-Gomar F, Martinez-Bello VE, Olaso-Gonzalez G, Gambini J, et al. Pharmacological properties of physical exercise in the elderly. Curr Pharm Des. 2014;20(18):3019-29.

66. Lianov $L$, Johnson M. Physician competencies for prescribing lifestyle medicine. JAMA. 2010;304(2):202-3.

67. Bodai BI, Nakata TE, Wong WT, Clark DR, Lawenda S, Tsou C, et al. Lifestyle Medicine: A Brief Review of Its Dramatic Impact on Health and Survival. Perm J. 2018:22:17-025.

68. Polak R, Pojednic RM, Phillips EM. Lifestyle Medicine Education. Am J Lifestyle Med. 2015;9(5):361-7.

69. Peleias M, Tempski P, Paro HB, Perotta B, Mayer FB, Enns SC, et al. Leisure time physical activity and quality of life in medical students: results from a multicentre study. BMJ Open Sport Exerc Med. 2017;3(1):e000213.

70. Stanford FC, Durkin MW, Stallworth JR, Powell CK, Poston MB, Blair SN. Factors that influence physicians' and medical students' confidence in counseling patients about physical activity. J Prim Prev. 2014;35(3):193-201.

71. Vickers KS, Kircher KJ, Smith MD, Petersen LR, Rasmussen NH. Health behavior counseling in primary care: provider-reported rate and confidence. Fam Med. 2007;39(10):730-5.

72. Jaques $\mathrm{R}$, Loosemore $\mathrm{M}$. Sports and exercise medicine in undergraduate training. Lancet. 2012;380(9836):4-5.

73. Young A, Gray JA, Ennis JR. 'Exercise medicine': the knowledge and beliefs of final-year medical students in the United Kingdom. Med Educ 1983;17(6):369-73. 
74. Oluwajana F, Rufford C, Morrissey D. Exercise, sports and musculoskeletal medicine in UK medical school curricula: a survey. British Journal of Sports Medicine. 2011;45(2):e1.

75. Cullen M, McNally O, Neill SO, Macauley D. Sport and exercise medicine in undergraduate medical schools in the United Kingdom and Ireland. $\mathrm{Br} \mathrm{J}$ Sports Med. 2000;34(4):244-5.

76. Garry JP, Diamond JJ, Whitley TW. Physical activity curricula in medical schools. Acad Med. 2002;77(8):818-20.

77. Weiler R, Chew S, Coombs N, Hamer M, Stamatakis E. Physical activity education in the undergraduate curricula of all UK medical schools: are tomorrow's doctors equipped to follow clinical guidelines? Br J Sports Med. 2012;46(14):1024-6.

78. Pugh G, O'Halloran P, Blakey L, Leaver H, Angioi M. Integrating physical activity promotion into UK medical school curricula: testing the feasibility of an educational tool developed by the Faculty of Sports and Exercise Medicine. BMJ Open Sport Exerc Med. 2020;6(1):e000679.

79. Connaughton AV, Weiler RM, Connaughton DP. Graduating medical students' exercise prescription competence as perceived by deans and directors of medical education in the United States: implications for Healthy People 2010. Public Health Rep. 2001;116(3):226-34.
80. Maybin RP. Health centres and the family doctor. J R Coll Gen Pract. 1972;22(119):365-75.

81. Booth ML, Bauman A, Owen N, Gore CJ. Physical activity preferences, preferred sources of assistance, and perceived barriers to increased activity among physically inactive Australians. Prev Med. 1997;26(1):131-7.

82. Brasil. Ministério da Educação. Conselho Nacional de Educação. Câmara de Educação Superior. Resolução №. 3 de 20 de junho de 2014. Institui diretrizes curriculares nacionais do curso de graduação em Medicina e dá outras providências. Diário Oficial da União, Brasília. 2014;23 jun. 2014(Seção 1):8-11.

83. McKenzie KJ, Pierce D, Gunn JM. A systematic review of motivational interviewing in healthcare: the potential of motivational interviewing to address the lifestyle factors relevant to multimorbidity. J Comorb. 2015;5:162-74.

84. Sibille K, Greene A, Bush JP. Preparing Physicians for the 21 Century: Targeting Communication Skills and the Promotion of Health Behavior Change. Ann Behav Sci Med Educ. 2010;16(1):7-13. 